\title{
DETERMINANTS OF EXPORT COMPETITIVENESS OF AGRICULTURAL PRODUCTS IN MALAYSIA
}

\author{
Siew-Ling Liew* \\ UCSI University, Sarawak, Malaysia \\ Mohammad Affendy Arip \\ Universiti Malaysia Sarawak, Malaysia \\ Chin-Hong Puah \\ Universiti Malaysia Sarawak, Malaysia
}

\begin{abstract}
This study intends to evaluate the export competitiveness of agricultural products using the data of 186 agricultural commodities in Malaysia for the period ranging from 1988 to 2014. Besides, this study engages in the total export of the world with Standard International Trade Classification Revision Three-SITC Revision 3 (5-digits code) to analyse the index of comparative advantage of agricultural commodities in Malaysia. In addition, the study employs Balassa (1965) index of Revealed Comparative Advantage (RCA) to measure competitiveness. The findings show that 56 commodities have comparative advantage. Apart from that, this study also empirically examines the determinants of competitiveness which are commodities price, GDP per capita, labour participation and capital formation. The results of cointegration tests estimation indicates that there is a long-run relationship between the variables under study. The outcomes denote that price of commodities, GDP per capita and crises in 2008 have negative association while labour participation and capital formation are positively relatedly to competitiveness. The results also specify that there is a short-run dynamic impact on competitiveness with the variables. This study suggests that the government should consider intensifying the current economic policy through focusing on downstream products by taking the benefit of its comparative advantage in upstream industries to increase competitiveness.
\end{abstract}

Keywords: Revealed Comparative advantage (RCA), Competitiveness, Export.

Received: 14 May 2019

Accepted: 10 May 2021

https://doi.org/10.33736/ijbs.3747.2021

\section{INTRODUCTION}

The world population has seen doubled from 2.9 billion in 1960 to more than 6.7 billion in 2008 . Fortunately, this trend has been countered by the stable growth of the output of agricultural coupled with a continuing drop in the prices of real commodity (Wik et al., 2008). However, in 2050 the world population is expected to grow to almost 10 billion. Despite of the promising demand for food in the both upstream and upstream industrial activities, agriculture sector has

- Corresponding author: UCSI University, Sarawak. Lot 2864 (P/L 1319), Block 7, Muara Tebas Land District, Isthmus, Tanjong Seberang Pending Point, Sejingkat, 93450, Kuching, Sarawak; Tel: 0168922066; E-mail address: lornaliew@ gmail.com 
shown a very slow pace of growth rate as compared to other economic sectors. This is especially true in many developing countries, notwithstanding the fact that agriculture sector is contributing to the majority of job opportunity. The reason being is the backwardness of agricultural activities. At the same time, the role of agricultural sector for food supply has been trembled by demand for biofuel.

Against this background, therefore it is vital to identify the productivity of agricultural subsector so as to make sure corrective measures can be implemented at the optimal cost. However, measuring productivity of various crops production can be very tedious since productivity requires assessment at micro level. From the macro perspective, productivity can be associated with the concepts of comparative advantage. Generally, comparative advantage is an economic theory which is based on the concepts of opportunity costs as well as relative efficiency in regards to resource use. For instance, the theory of comparative advantage by Ricardo indicated that lower opportunity costs for the production of a certain good relative to other goods will lead to competitiveness. Therefore, a country will concentrate in producing goods with comparative advantage, whilst on the other hand, it will trade with other countries for goods in which it has a comparative disadvantage for the benefit of each other. Other than that, competitiveness is known as the capability and achievement of a firm, sub-sector or country to market and source goods and services. The relative prices amongst competitors have impact towards the exportation and market share's level. This determines if the products are inexpensive in that particular country as compared to others, giving the exporting country added competitiveness. Schwab and Sala-i-Martín (2014, p.4) defined competitiveness as "the set of institutions, policies, and issues that define the productivity level of a nation". They initiated that the productivity level determines the wealth as well as the profit gained through investments of an economy that result in economic growth.

\subsection{Agriculture Background in Malaysia}

In Malaysia, the agriculture sector makes up the largest share of national output other than the manufacturing sector, creating job opportunities for labourers (Diao et al., 2007). The agriculture sector has several sub-sectors including; palm oil, rubber, livestock, forestry and logging, fisheries, aquaculture as well as other agriculture such as paddy, fruits, vegetables, coconut, and more. According to Malaysia Productivity Corporation (MPC, 2015), Malaysia's agriculture sector contributes to national income and has the potential to support the Ringgit's foreign exchange valuation. This occurs during this time of huge world demand for agricultural products owing to a rising population in the world as well as strong economic fundamentals.

According to the World Economic Forum Competitiveness Report (WEF, 2015), Malaysia was rated as the 18th most competitive economy in the world, additionally Malaysia remains the highest ranked among the developing Asian economies. Therefore, Malaysia has to remain competitive in this era of globalisation as competitiveness is essential to many countries in order to be assured of growing living standards and economic growth (Ariff, 2005). However, the increasing level of international trade, especially in the manufacturing sector, has reduced the importance of the agriculture sector among policy makers, academics and policy analysts. This is partly caused by the low prices of agricultural commodities in world markets as well as the low level of technology being used in the agricultural sector. According to Adelman (2001), economic development as a growth process requires an organised restructuring of the factors of 
production. As a main sector, the agriculture sector has lower productivity, does not contribute to technology advancement, and has yielded decreasing returns. This has made the agriculture sector less attractive and thus, it is important that the sector embraces new technologies while constantly boost the ability and expertise of its labour so as to attain a change in operation (MPC, 2015). Hence, the transformation from a traditional sector to a modern sector will help to achieve a higher level of productivity and increasing returns to upsurge its competitiveness.

Figure 1 depicts the GDP performance of the agriculture sector in Malaysia from 1988 to 2015. The figure shows that agriculture sector had experienced a slight decrease to 9.3 percent of GDP growth in 2009 (from RM76,753 million in 2008). Unfortunately, like many other countries including Malaysia could not escape the global financial crisis that happened back in 2008-2009. The crisis affected the agriculture sector in which the agriculture and natural resource exports declined despite commodity prices dropping. The decline in the commodity price did not stimulate exports of the commodity products as the global economy had slowed down and this reduced export demand for the commodity products. The sector's contribution to GDP witnessed an increase of RM16,895 million to RM82,614 million in 2010 and the GDP growth rate grew marginally to 10.5 percent (see Figure 1.2). The sector continued to expand at 1.4 percent to 11.9 percent with a recorded GDP amounting to RM104,301 million in 2011. This upward trend might be due to the greater production of palm oil and food commodities such as vegetables and fruits, and poultry. According to MPC (2015, p.73), the palm oil sub-sector played a huge role in the agriculture sector whereby it contributed about 36.6 percent to the GDP, followed by other agriculture sub-sectors such as fisheries and aquaculture which contributed 20.1 percent and 14.6 percent, respectively. Regardless of a recorded decline of the agriculture sector in terms of growth rate from 11.9 percent in 2011 to 10.2 percent in 2012 and further declined to 9.4 percent and 9 percent in 2013 and 2014 respectively, the agriculture sector remained crucial to the nation's development. For this reason, this study intends to assess the export competitiveness of agricultural products in Malaysian agriculture sector.

Figure 1: GDP Performance on the Agriculture Sector in Malaysia, 1988-2015

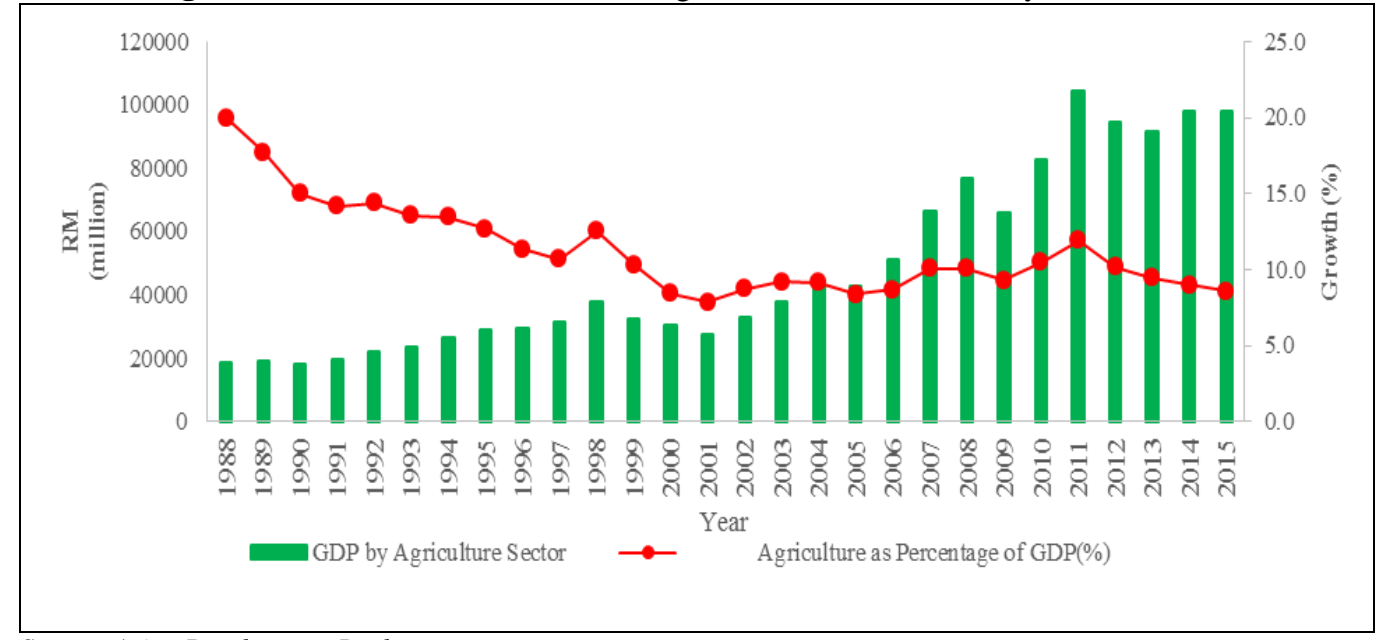

Source: Asian Development Bank. 


\section{LITERATURE REVIEW}

Aziz (2013) discovered that rising price of commodities reduces competitiveness and therefore cause a decline in production. Based on the first estimation results obtained, the oil price was found to be significantly less than zero for 70 percent of the RCA commodities. Besides, they found that oil price fluctuations significantly affected the competitiveness from 1997 to 2005 based on the third regression. In contrast, the findings of the second estimation revealed that oil price fluctuations negatively affected the competitiveness. In addition, the fourth estimation also showed a negative association between the price of commodities. Such finding is owing to the fact that increase in the price of agricultural products will lead to drop in demand as the price of agricultural products is expensive, and this in turn results in loss of competitiveness in the agriculture export. Therefore, growth in the commodities' price consequently led to a loss of competitiveness in the tradable sector that triggered exchange rates to appreciate due to the movement of resources to a growing sector. This can be supported by the discovery of Cvetković and Petrović-Ranđelović (2017) who stated that low price of agricultural products is one of the major aspects of export competitiveness.

Bhattacharya (2011) stated that income is expected to linked positively with competitiveness in which the import volume will expand as GDP increases. However, the findings showed that the export demand for onions and mangoes by Malaysia to the European Union have a negative relationship with the per capita income of the European Union. In contrast, a positive association existed between export demand for onions, mangoes and fresh flowers with the per capita income of the European Union for China, Thailand and Indonesia. This is due to the possibility of downward processing of the commodities value addition executed in the final products which has better quality.

Based on the study of Joshi et al. (2004), it was hypothesised that the per capita income is able to influence diversification on the demand side. This is because growing per capita income lead to growth in demand for livestock products in the consumption which lead to export diversification of livestock sector. This indicated that the diversification of agricultural commodities increases as the per capita income rises as this enable a country to look into other ways to develop its basic commodities into high-value-added commodities. This eventually will lead to the competitiveness in that particular commodity in terms of its comparative advantage as compared to commodities without value-added.

Zhu (2012) stated that an increase in the participation of labour increases productivity growth, and ultimately, the comparative advantage of China. This is because increase in labour participation will lead to upsurge in the productive capacity which allows for reduction in the cost of their output that results in export competitiveness. In addition, labour participation and export competitiveness is positively linked and it is driven by productivity (Zhu, 2012; Madsen $\&$ Ang, 2013). This is because higher agricultural produce means improved competitiveness where people will benefit from better and cheaper products that eventually lead to competitiveness in its exportation. Furthermore, Edeme et al. (2016) indicated that the labour participation rate has a positive association with competitiveness in the ECOWAS region. Thus, they concluded that the rise in the labour participation rate would initiate competitiveness and economic growth. Alternatively, Abdychev et al. (2014) pointed out a negative influence of labour participation rates, especially among female workers. However, the relationship turned 
positive after adjusting the share of the agriculture sector to the GDP, and this illustrated that most women were involved in low-end productivity in the agriculture sector.

A research study done by the Food and Agriculture Organization of the United Nations (FAO, 2012) indicated that the spending on capital formation is able to form an environment for improved infrastructure and sustainable access to natural resources. Furthermore, it also contributes a positive and significant impact on productivity and competitiveness. The research revealed that a 0.34 percent upsurge in a country's agriculture total factor productivity is possible when there is an increment of 10 percent in public spending on agriculture. Apart from that, Mehrara and Baghbanpour (2016) pointed out that gross fixed capital formation had the ability to affect the competitiveness of the outputs which in turn would cause an upsurge in economic growth due to the export of goods through returns of scale and increased efficiency.

\section{METHODOLOGY}

For analytical purposes, this study used annual exportation data of 186 agricultural related commodities in Malaysia for the empirical period of 1988 to 2014. This study will engage in the total export of the world. The exportation data for these commodities ${ }^{1}$ is obtained from the United Nations Commodity Trade Statistics Database (UN Comtrade Database) ${ }^{2}$ with the Standard International Trade Classification Revision Three-SITC Revision 3 (5-digits code) to analyse the index for the comparative advantage of agricultural commodities in Malaysia.

This study intends to examine the competitiveness of agricultural products in Malaysia. For this purpose, a method that measures the production capacity of one country against the rest of the world is adopted. Most researchers have preferred to use the standardised net export shares measurement which is known as the revealed comparative advantage (RCA) as developed by Balassa (1965) in order to determine the comparative advantage of a certain commodity or product in the market. RCA is defined as a measurement of comparative advantage of a country which is built on the relative export ratio of a particular commodity in that particular country against that of the world (Balassa, 1965). The RCA index was pioneered by Balassa (1965) and it has grown to become a useful empirical research on the patterns of trade. However, the RCA measurement may not be able to differentiate between the effects of factors endowment from the policy of trade. Nevertheless, it does provide a sign regarding the flow of comparative advantage in a region (Bender \& Li, 2002). Based upon the findings of Aini et al. (2010), the RCA measurement has a role in quantifying the commodity-specific degree of comparative advantage. In addition, RCA indices provide a beneficial guide to the underlying comparative advantage and offer a further understanding into the competitiveness of the Malaysian agricultural related commodities.

Therefore, to measure the RCA index of the Malaysian agricultural products, the formula developed by Balassa (1965) has been used in estimating comparative advantage and the RCA index is computed from Equation 1. Equation 1 calculates the relative export ratio of a particular

\footnotetext{
${ }^{1}$ To conserve space, the 186 agricultural related products in Malaysia are not presented here but they are available upon request from the authors.

${ }^{2}$ See more information for UN Comtrade Database: http://comtrade.un.org/
} 
commodity against the total export of one country to the relative ratio of the total exports of the same commodity against the total export value for the world. The underlying reason for the application of relative export rather than the net-export is rested upon the system of trade protection. Balassa (1989, p.26) clarifies that protection has a great influence on the inter-country trade pattern. Thus, to neutralise the effect of protectionism and to get a uniform index of "revealed" comparative advantage, the measurement has to rely on the relative export value (Balassa, 1989).

$$
R C A_{i}^{j}=\frac{X_{i}^{j} / X_{i}^{j}}{X_{i}^{w} / X_{t}^{w}}
$$

where,

$\mathrm{RCA}=$ Index of revealed comparative advantage; $x_{i}^{j}=$ Export of commodity $\mathrm{i}$ by country $\mathrm{j} ; x_{t}^{j}$

$=$ Total export of country $\mathrm{j} ; x_{i}^{w}=$ Export of commodity in the world; $x_{t}^{w}=$ Total export of the world

If the obtained RCA value is larger than one, this shows that country $\mathrm{j}$ has a positive impact or comparative advantage in the production of $i$ and vice versa. Put simply, the greater the index of RCA, the stronger the comparative advantage will be. Conversely, the smaller the index, the bigger the comparative disadvantage.

After generating the index of RCA, this study is carried on by analysing the collected data using the Eviews 9.0 software to find the determinants of competitiveness of agriculture sector in Malaysia. In order to examine the stationary properties of all of the variables under study, the Augmented Dickey-Fuller (ADF) and the Phillips-Peron (PP) unit root tests will be performed. Meanwhile, the bounds test for cointegration and the ARDL test will be conducted to obtain the long-run estimates and the ECM from the ARDL model. Additionally, a series of diagnostic and stability tests were carried out to ascertain the appropriateness of the ARDL model.

The following functional form is employed in the analysis of the determinants of the revealed comparative advantage (RCA) of Malaysian agriculture sector. The model for the RCA is expressed as below:

$$
\text { LOGRCA }_{t}=\alpha+\beta_{1} \text { LOGPM }_{t}+\beta_{2} \text { LOGGDPC }_{t}+\beta_{3} \text { LOGLABOUR }_{t}+\beta_{4} \text { LOGCAPFORM }_{t}+\varepsilon_{t}
$$

where,

LOGRCAt $\quad=$ Log of indicator for the revealed comparative advantage for Malaysia at period $\mathrm{t}$

$\operatorname{LOGPM}_{t} \quad=$ Log of the price for agricultural commodities in Malaysia at period $\mathrm{t}$

$L O G G D P C_{t} \quad=$ Log of the GDP per capita at period $\mathrm{t}$

$L O G L A B O U R_{t}=\log$ of the labour participation rate in the agriculture sector at period $\mathrm{t}$

LOGCAPFORM $t=\log$ of capital formation in the agriculture sector at period $\mathrm{t}$

$\alpha \quad=$ Constant 
The rationale for using the above-mentioned independent variables is because they are important variables that can influence comparative advantage. Local price is adopted in this study because the competitiveness of one product can be reflected by the price of commodities. Increase in the price of agricultural products will lead to drop in demand as the price of agricultural products is expensive, and this in turn will caused the products to be less competitive in the agriculture export (Tuah, 2013). As such, this can depict how changes in price can have an impact on the revealed comparative advantage.

Adjusting GDP in agriculture sector to population is used in this study because it is an indicator of the level of economic development. It also takes into account the effect of the distribution of income among rural households, this enabled the impact of poverty alleviation strategies to be observed, and in particular the livelihoods of rural dwellers (Mucavele, 2010). Bhattacharya (2011) showed that the export demand for onions and mangoes by Malaysia to the EU tended to have a negative relationship with the per capita income of the EU, whereas a positive association existed between export demand for onions, mangoes and fresh flowers with the per capita income of the EU for China, Thailand and Indonesia. Besides, Pham and Riedel (2013) stated that the per capita income has the ability to upsurge the comparative advantage.

The basis of using the labour participation rate is due to its possible effect on economic growth. According to Verick (2014), economies can grow at a faster pace in response to higher labour inputs in regards to an increase in the participation rate of the labour force. As such, this could have a significant impact on both productivity and growth. Besides, Aziz (2013) reported that labour would capture the relative differences in factor endowments among countries. Zhu (2012) and Madsen and Ang (2013) pointed out that the labour participation rate and productivity growth has a positive association, thus leads to comparative advantage.

Capital formation was added in this study because with the net investment in capital goods such as equipment, machinery, infrastructure and technology enable the agriculture sector to produce efficiently at a reasonably low price. Besides, capital formation upsurges capacity in production and, by enhancing labour productivity, contributes to the competitiveness of firms and sectors through higher value-added outputs. This, in turn, will speed up the rate of technological advance and innovation across the economy which will eventually generate investment as well as income to the economy (Mehrara \& Baghbanpour, 2016; Malik, 2012; European Commission, 2007). As a whole, investment in capital formation is important to promote long-run economic growth by improving productivity and capacity.

\section{RESULTS AND DISCUSSION}

The generated RCA results ${ }^{3}$ showed that only 56 agricultural related commodities had RCA during the empirical period. The results clearly revealed that Malaysia had a comparative advantage in the exportation of these products. However, not all of these agriculture related commodities have had a comparative advantage throughout the 27 -year period.

\footnotetext{
${ }^{3}$ Refer to Appendix A for the results of agricultural products with Revealed Comparative Advantage.
} 
Furthermore, the results also exposed that Malaysia was competitive in the production of the commodity with SITC code S3-03611 (shrimps and prawns, frozen) in 1988. However, Malaysia had a comparative disadvantage in the exportation of this agriculture product for the following 11 years. Nevertheless, the RCA index upsurged from 1.033 in 2000 to 1.129 in 2001, and then further declined to 1.029 in 2014. Besides, the commodity with SITC code S3-04813 (Other rolled or flaked cereal grains, except rice of subgroup 042.3) had a comparative advantage throughout the years, except for 2014. In contrast, the RCA index for some of the agricultural commodities is lower than one in the estimated period. As a result, this showed that Malaysia had a comparative disadvantage in the exportation of these agricultural products.

Specifically, the results of RCA also revealed that only 10 commodities had a comparative advantage from 1988 to 2014, namely they are S3-07511, S3-08138, S3-23125, S3-42119, S342229, S3-42239, S3-42241, S3-42249, S3-43131 and S3-43133. However, the RCA index showed an irregular trend. For example, the RCA index of S3-07511 showed that it decreased from 6.782 in 1988 to 4.886 in 1999 . The RCA index then increased about 0.146 to 5.032 in 2000 and it declined further to 1.616 in 2013. This is owing to the fluctuation of price of pepper where the global demand exceeds the supply (Ministry of Plantation Industries and Commodities (MPIC), 2016). According to MPIC (2016), pepper recorded a huge amount at over RM500 million in 2015. For instance, Malaysia exports pepper to Japan, China and Taiwan in which these countries emphasised a lot on the quality of the products. Therefore, innovation in pepper is needed in order to ensure that it has the quality to increase value-added and to be competitive in the export market. In 1988, the commodity with SITC code S3-23125 had the highest RCA index which was 22.086. This indicated that Malaysia had a higher comparative advantage on the exportation of S3-23125 in 1988 as compared to all other agricultural related commodities. This is due to the popularity of rubber and demand for rubber increased especially for its compatible ramin wood which was short in supply during late 1980s (Lembaga Getah Malaysia, 2011). Despite the fact that value-added elements exist in rubberwood, the price of rubber remained low and this has contributed to the competitiveness of rubber. In addition, the RCA index for S342241 dropped tremendously after year 1991 and only increased from 11.494 in 2013 to 14.270 in 2014. Therefore, this finding showed that there is possibility of shifting these commodities further into downstream processing as the index indicated comparative advantage existed.

Moreover, RCA results illustrated that Malaysia documented high RCA indices namely for products with SITC code S3-08138 (oilcake and other solid residues of oil from palm nuts or kernel), S3-42229 (palm oil, refined, and its fractions) and S3-42249 (palm kernel or babassu oil, refined, and fractions thereof) as compared to other agricultural commodities throughout the study period. This is clear since Malaysia is one of the major producers as well as exporters of palm oil. According to the Malaysia Palm Oil Council (2013), Malaysia recorded a number of 39 percent of world palm oil production and 44 percent of world exports. However, Arip et al. (2013) indicated that being one of the largest producers of crude and refined palm oil does not necessarily lead to diversification and expansion or specialisation in the agriculture industry which brings about higher value-added products. It is essential for the agriculture sector to move from the low to high value-added sector from time to time in order to sustain the long-term development of the agriculture sector (Arip et al., 2013). In the case of the palm oil industry, its comparative advantage can be retained by moving from upstream to a broader scope of downstream industrial products that will add higher value-addition to the content. 
To simplify the discussion, the results of Malaysia-world total trade value of comparative advantage and disadvantage for agricultural commodities based on SITC Revision 3 (3-digits code $)^{4}$ has been analyzed. Then, a total of 40 agricultural commodities ${ }^{5}$ based on the 3 -digits code have been identified. The results revealed that Malaysia has the highest number of commodities with a comparative advantage in the exportation of products S3-422 (Fixed vegetable fats and oils, crude, refined or fractioned, other than "soft") in 1990. Specifically, the commodities that fall under this group are S3-42249, S3-42241, S3-42239, S3-42231 and S342229. However, it is noticeable that most of the agricultural products that fall under S3-422 are still at the refining stage although Malaysia is one of the largest producers of S3-422. This means that Malaysia do not produce the commodity further into end product such as cosmetics, soaps or detergents. Therefore, to further enhance the export competitiveness requires shifting the production process from upstream to downstream processing so as to create higher value-added.

In 2010, the RCA index for S3-42249, S3-42241, S3-42239 and S3-42229 were 21.096, 3.588, 4.840 and 18.627 , respectively with a trade value amounting to US\$1104.9 million. Although the volume of total trade had increased tremendously after 2010, the value of the RCA index is in a decreasing trend. For example, RCA results showed that the RCA index for S3-42249 declined from 2010 to 2014. As for commodity S3-42241, the RCA index increased throughout the years from 2010 to 2014. Nevertheless, the increase in the value of the RCA index did not necessarily mean that the sector was performing well because high RCA values do not inevitably entail that countries manage to utilise their potential (Nilsson et al., 2007). Furthermore, Welfen et al. (2009) stated that a booming export market also does not reflect the competitiveness of a country or that it is dealing well with the challenges of structural change.

Based on the analysis SITC Revision 3 of Malaysia-world total trade value of comparative advantage and disadvantage, Malaysia has the greatest level of comparative disadvantage in the exportation of products S3-054, S3-056 as well as S3-057. The reason for such findings is that Malaysia still depends on the import of agricultural products for fruits and vegetables from other countries to meet the demand of its local market while Malaysia is actually capable of producing most of the vegetables it imports (Ruban, 2016). Therefore, it is crucial to move from upstream production of basic agricultural products to downstream production of value-added products in order to boost the exportation in agriculture.

Furthermore, Malaysia had only one commodity with comparative advantage in 2005, 2010, 2011, 2012, 2013 and 2014. In contrast, commodities that fell under the sub-group of S3-056 had recorded a number of 14 commodities with comparative disadvantage where the trade value continues to expand except for 2014. The findings also clearly showed that there is a huge gap in the trade value between comparative advantage and comparative disadvantage. The commodity with SITC code S3-057 (Fruit and nuts [not including oil nuts], fresh or dried) illustrated that a comparative advantage only existed in 1990, 1995, 2000 and 2005, whereas the number of commodities that indicated a comparative disadvantage increased from 16 in 2005 to 17 commodities from 2010 onwards. The trade value for S3-057 in 1990 was US\$47.0 million, and it declined to US\$33.8 million in 1995 when it was left with one commodity with an

\footnotetext{
${ }^{4}$ To conserve space, the results of Malaysia-World total trade value of comparative advantage and disadvantage for agricultural commodities based on SITC Revision 3 are not presented here but they are available upon request from the authors.

${ }^{5}$ To conserve space, the list of 40 agricultural commodities based on 3-digits code is not presented here but they are available upon request from the authors.
} 
improvement of 1.246 in terms of its comparative advantage for S3-05791. This is due to the fruits commodity could be experienced shortage of supply and this reduce the opportunity for Malaysia to penetrate the market for exportation to fulfil the insufficient domestic demand (Abdul Rahim, 2014).

In short, the results illustrated that a high RCA index does not signify the real performance of the commodities without taking into account the trade volume. This is because exports of these products are mostly as raw and unprocessed commodities that do not contribute much valueadded, in spite of the fast-growing volume of export. Therefore, Malaysia needs to move from the export of raw materials to the export of processed products in order to increase the valueadded element of the commodity (Le, 2010).

Prior to testing cointegration, the order of integration for each variable had been tested using $\mathrm{ADF}$ and PP tests. The obtained results disclosed that the selected variables in this study are in a combination of both $\mathrm{I}(0)$ and $\mathrm{I}(1)$ processes, justifying the use of Autoregressive-Distributed Lag (ARDL) estimator. To conserve space, the results of ADF and PP tests are not presented here but they are available upon request from the authors. Bounds testing and the ARDL tests introduced by Pesaran et al. (2001) was employed in the next stage to study the long-run equilibrium relationship of the indicated variables in the model since the series do not have the same order of integration in unit root tests estimation. This is due to bounds testing does not enforce restrictive assumptions that all of the underlying variables must be integrated in the similar order (Choong et al., 2003; Choong et al., 2005).

Hence, the bounds testing approach to cointegration was employed in the next stage to study the long-run equilibrium relationship of the indicated variables in the model. As presented in Table 1, the F-statistic computed under the bounds test by the revealed comparative advantage model is 9.048. This value clearly showed that it is greater than the upper bound of the critical values at the 5 percent level of significance as presented in Pesaran et al. (2001) and Narayan (2005). Therefore, it can be concluded that there exists a long-run relationship between the test variables.

Table 1: Results of Bounds Test for Cointegration

\begin{tabular}{cccccc}
\hline \hline F-statistic & Significant level & \multicolumn{2}{c}{ Pesaran Critical Values } & \multicolumn{2}{c}{ Narayan Critical Values } \\
\hline & & $\mathbf{I}(\mathbf{0})$ & $\mathbf{I}(\mathbf{1})$ & $\mathbf{I}(\mathbf{0})$ & $\mathbf{I}(\mathbf{1})$ \\
\hline \multirow{3}{*}{9.048} & $90 \%$ & 2.2 & 3.09 & 2.52 & 3.56 \\
& $95 \%$ & 2.56 & 3.49 & 3.05 & 4.22 \\
& $99 \%$ & 3.29 & 4.37 & 4.28 & 5.84 \\
\hline \hline
\end{tabular}

Notes: Critical values are obtained from Pesaran et al. (2001), table Case II: restricted intercept and no trend, and Narayan (2005), table Case II: restricted intercept and no trend.

After verifying the existence of long-run relationship, this allows the long-run parameters analysis to be estimated. Table 2 showed the generated long-run cointegration estimates in regards to revealed comparative advantage model. The test statistic for the RCA model indicated that the LOGPM, the LOGGDPC and crises are negatively related to the RCA, whereas the LOGLABOUR and the LOGCAPFORM variables had a positive relationship with the RCA. This showed that increase in the price of agricultural products will lead to drop in demand as the price of agricultural products is expensive, and this in turn results in loss of competitiveness in 
the agriculture export (Tuah, 2013; Aziz, 2013; Cvetković \& Petrović-Ranđelović, 2017). Besides, Othman et al. (2009) indicated that highly priced agricultural products will impede the competitiveness and its value-added products in the export market.

Meanwhile, the LOGDPC variable has a negative coefficient sign which is consistent with the past findings of Bhattacharya (2011). It is undeniable that the GDP has the ability to contribute to a country's the economic growth. However, the obtained result is deemed possible as the contribution from the GDP in Malaysia is possibly diverted to other sectors such as the services sector and the manufacturing sector as these sectors account for a bigger share of the economy. For example, Bank Negara Malaysia (BNM) (2016) reported that the services sector recorded a continuous growth of 5.1 percent in the first quarter of 2016 as compared to the fourth quarter of 2015 which was 5 percent. In addition, the manufacturing sector continued to grow at a level of 4.5 percent in the first quarter of 2016. On the other hand, growth in the agriculture sector contracted by 3.8 percent in the first quarter of 2016 from 1.5 percent in the fourth quarter of 2015. Therefore, this initiates that most of the resources have been allocated and have been emphasised on to these sectors in Malaysia. In short, the other sectors overtook agriculture to become the leading sectors of the economy in Malaysia and it has affected the competitiveness of the agriculture sector (Malaysian Investment Development Authority (MIDA, 2016); Tengku Ahmad \& Suntharalingam, 2009).

As for the LOGLABOUR variable, the estimated empirical results displayed that it is statistically significant at the 1 percent level and positively linked to comparative advantage, which implies that as the LOGLABOUR variable increases, the comparative advantage will rise too. The obtained result is deemed plausible in the case of Malaysia because immigrant workers have become one of the main sources of labour especially in labour intensive sectors, namely, the agriculture sector (Moreno, 2016; Ismail \& Yuliyusman, 2014). This is in line with the findings discussed by Zhu (2012) who documented that a positive association existed between the labour participation rate and productivity growth and this helped to boost the comparative advantage in China.

Table 2: ARDL Estimation Results of the Revealed Comparative Advantage Model

\begin{tabular}{cc}
\hline \hline Regressor & Revealed Comparative Advantage Model (1,2,2,1,1) \\
& LRCA \\
\hline Constant & -1.378 \\
& $\{-0.703\}$ \\
LOGPM & {$[0.495]$} \\
& $-0.272 * * *$ \\
LOGDPC & $\{-3.262\}$ \\
& {$[0.007]$} \\
& $-0.688 * * *$ \\
LOGLABOUR & $\{-10.906\}$ \\
& {$[0.000]$} \\
& $0.557 * * *$ \\
& $\{2.329\}$ \\
& {$[0.038]$}
\end{tabular}


LOGCAPFORM $0.227 * * *$

$\{4.224\}$

[0.001]

DUM2008

$-0.100 * * *$

$\{-1.951\}$

[0.007]

Notes: Asterisk $(* * *)$ denotes the rejection of null hypothesis at $1 \%$ significant level, respectively. The figures in $(\ldots)$ refer to the selected lag length based on AIC. The figures in $\{\ldots\}$ and $[\ldots]$ refer to the $t$-statistics and probabilities, respectively.

Furthermore, the coefficient of the LOGCAPFORM is statistically significant at the 1 percent level. In the case of Malaysia, the allocation of capital formation in the agriculture sector in Malaysia has witnessed a growth from 7.3 percent in 2014 to 8.3 percent in 2015 (Department of Statistics Malaysia (DOSM), 2016). With such an improvement in capital formation in the agriculture sector, Malaysia is competent to enhance the competitiveness of its agricultural products in terms of the quality of the output. This is deemed plausible as growth in addition to capital formation will lead to the efficiency in resource allocation due to the comparative advantage. Consequently, this, in turn, will boost productivity.

This model also takes into account a dummy variable created due to the 2008 global financial crisis and which triggered economic growth towards the agriculture sector and also caused other sectors such as the manufacturing sector to slow down. The significance of the dummy variable implied that the global financial crisis and food crisis which occurred in 2008 had an adverse effect on the comparative advantage of the agriculture sector in Malaysia.

Next, the error-correction term (ECT) is presented in Table 3. The ECT values for the revealed comparative advantage model have been generated from the error correction model based on the cointegration framework. The obtained ECT values are reported in Table 4 where the ECT values has a negative sign and statistically significant at the 1 percent level. The coefficient of ECT is 0.989 , suggesting that a deviation from the long-term comparative advantage is corrected by 98.9 percent over the following year. In addition, a battery of diagnostic and stability tests was carried out to determine the robustness of the RCA model. The diagnostic tests result showed that the model is free from the problem of serial correlation, functional form, normality and heteroscedasticity.

Table 3: ARDL Results of Error-Correction Representation for the Selected ARDL Models

\begin{tabular}{ll}
\hline \hline & Revealed Comparative Advantage Model \\
\hline Regressor & Coefficient $[t$-statistic $]$ \\
\hline D(LOGPM) & $-0.078[-1.448]$ \\
D(LOGPM(-1) & $0.152[3.438]^{* * *}$ \\
D(LOGGDPC) & $-0.717[-15.587]^{* * *}$ \\
D(LOGGDPC(-1)) & $-0.109[-2.371]^{* *}$ \\
D(LOGLABOUR) & $0.034[0.367]$ \\
D(LOGCAPFORM) & $-0.029[-0.656]$ \\
D(DUM2008) & $-0.106[5.196]^{* * *}$ \\
ECT & $-0.989[-8.783]^{* * *}$ \\
Diagnostic Tests: & \\
JB & $0.049[0.976]$ \\
AR [2] & $0.766[0.202]$
\end{tabular}




\begin{tabular}{ll} 
ARCH [1] & $0.031[0.854]$ \\
RESET [1] & $0.051[0.825]$ \\
CUSUM & Stable \\
CUSUM $^{2}$ & Stable \\
\hline
\end{tabular}

Notes: JB is the Jarque-Bera statistic for testing normality, AR[2] and ARCH[1] are the Lagrange Multiplier test for 2nd order serial correlation and ARCH effects, respectively. RESET refers to Ramsey RESET specification test while CUSUM is cumulative sum of residuals stability test and CUSUM2 is cumulative sum of squares of recursive residuals stability test. Asterisks $(* *)$ and $(* * *)$ denote the rejection of null hypothesis at $5 \%$ and $1 \%$ significant levels. The figures in $[\ldots]$ refer to the probabilities.

\section{CONCLUSION}

In this paper, we discussed the competitiveness of agricultural related commodities in Malaysia by utilising the Balassa (1965) RCA measurement for the period 1988-2014. Then, a set of independent variables were employed to find out the determinants of competitiveness. The results showed that 56 agriculture-related commodities had a comparative advantage. Nevertheless, not all of the agriculture-related commodities had comparative advantage throughout the study period. For instance, the results revealed that only 10 commodities had comparative advantage throughout the analysis period, specifically products with SITC code S307511, S3-08138, S3-23125, S3-42119, S3-42229, S3-42239, S3-42241, S3-42249, S3-43131 and S3-43133. However, the RCA index of the aforementioned commodities revealed an unstable trend during the period of analysis.

Malaysia is found to be more competitive for commodities with SITC code S3-08138 (oilcake and other solid residues of oil from palm nuts or kernel), S3-42229 (palm oil, refined, and its fractions) and S3-42249 (palm kernel or babassu oil, refined, and fractions thereof) as compared to other agricultural commodities. This is self-explanatory since Malaysia is one of the major producers as well as exporters of palm oil. However, Malaysia should have focus more on downstream processes by taking the benefit of its comparative advantage in upstream industries. We also take into account the total trade value of comparative advantage and disadvantage by simplifying the discussion into 3- digits code and 40 agricultural commodities had been identified. The reason for this is because high RCA indexes do not imply the real performance of commodities due to exportations of these products are mostly in the form of raw materials and unprocessed commodities and do not bring much value-added, in spite of the fast-growing volume of export.

We then employed econometric models to establish the empirical findings to identify the determinants affecting competitiveness of agriculture sector in Malaysia. The empirical results showed that price of commodities, GDP per capita and crises are negatively related to competitiveness in Malaysia. In contrast, labour participation and capital formation have positive impact on competitiveness. The diagnostic tests result illustrated that none of the models suffers from autocorrelation and misspecification problems, and the obtained parameters are also normally distributed with constant variance.

Given the importance of price of commodities in affecting competitiveness of agriculture sector in Malaysia as it determines the economic incentives necessary to encourage greater efficiency in the usage of resource. In general, increase in the price of agricultural products will lead to drop in 
demand as the price of agricultural products is expensive, and this in turn results in loss of competitiveness in the agriculture export. Besides, highly priced agricultural products will impede the competitiveness and its value-added products in the export market. Therefore, stable prices are important to provide domestic and investors from other countries with confidence and to allow farmers and traders to take informed, long-term decisions.

Moreover, noting that the agriculture sector's allocation of government resources has been stagnant in the past, an upsurge in the allocation made is needed in order to stimulate the growth of this sector. Such a policy recommendation is in parallel with the government effort stated in the 11th Malaysian Plan where the government aims to promote private investment in agriculture to spearhead competitiveness and diversifying markets (Economic Planning Unit (EPU), 2015). For example, a record level of private investment in excess of RM3 billion has been placed on palm oil downstream processing, covering a wide variety of products with higher value-addition from oleo derivatives such as bio-polyols and bio-lubricants to phytonutrients namely tocotrienols and carotene (EPU, 2015). However, Malaysia could also emphasised or taking benefit of comparative advantage on other upstream commodities instead of focusing only on mainstream commodities to increase its competitiveness.

Besides, it is undeniable that Malaysia is very much dependent on low-skilled foreign migrant workers, be it in the manufacturing, services or agriculture sectors although the aim of the policy is to produce higher value-added output (Ismail \& Yuliyusman, 2014; Moreno, 2016). This is owing to the fact that foreign workers are cost savings. Increase in labour participation will lead to rise in agricultural produce due to cheaper cost of hiring foreign workers. Therefore, it results in better bargaining power for agricultural products in the foreign market which help to boost the export performance of agricultural products in Malaysia through export earnings in international markets. In view of this, it is crucial to provide incentives or training that would result in more skilled labour force to encourage more labour participation in agriculture. This in turn enables agricultural products to be produced with better quality. Providing a good and attractive welfare system motivates workers to work harder as well as to raise the working efficiency. By and large, it will indirectly result in better performance that leads to export competitiveness.

It is also important to promote capital formation that will lead to competitiveness. According to MPC (2016), a low level of dynamic capabilities would only cause the sector to be engrossed in commodities and constrained by its ability to build high-value downstream outputs. Therefore, the Malaysian agriculture sector may need to further improve or modernise its capital formation in terms of tools, equipment and machinery so as to uplift productivity and competitiveness by encouraging more private investment in capital formation and upgrade its technological capabilities. Undoubtedly initiatives have been taken to boost private investment in the Malaysian agriculture sector such as the replanting and new planting of palm oil and rubber, and the upgrading of machinery and equipment (BNM, 2015). However, investment activities from the private sector has engaged only in the main commodities such as palm oil and rubber instead of aiming at other commodities such as the downstream processing of quality vegetables and fruits to achieve higher value downstream outputs that can eventually boost competitiveness. 


\section{ACKNOWLEDGEMENT}

The authors would like to express deepest appreciation to all those who provided the possibility to complete this paper.

\section{REFERENCES}

Abdul Rahim, N. A. Z. (2014). An Overview of Fruit Supply Chain in Malaysia. Jurnal Mekanikal, 37, 36-46.

Abdychev, A., Jirasavetakul, L. F., Jonelis, A., Leigh, L., Moheeput, A., Parulian, F., Stepanyan, A., \& Mama, A. T. (2014). Increasing Productivity Growth in Midle Income Countries. (IMF Working Paper No. 15/2). International Monetary Fund. https://www.imf.org/en/Publications/WP/Issues/2016/12/31/Increasing-ProductivityGrowth-in-Middle-Income-Countries-42595

Adelman, I. (2001). Fallacies in Development Theory and Their Implications for Policy. (Working Paper No. 887). Department of Agricultural and Resource Economics and Policy Division of Agricultural and Natural Resources.

Aini, Z. N., Roda, J. M., \& Fauzi, P. A. (2010). Comparative advantage of Malaysian wood products in the European market. Paper presented at the National Postgraduate Seminar (NAPAS 2010), Kuala Lumpur, Malaysia.

Ariff, M. (2005). The Drivers of Competitiveness in Malaysia. Malaysian Institute of Economic Research, Kuala Lumpur, Malaysia.

Arip, M. A., Lau, S. Y., \& Thien, S. F. (2013). Assessing the Competitiveness of Malaysia and Indonesia Palm Oil Related Industry. World Review of Business Research, 3(4), 138-145.

Aziz, M. I. A. (2013). Oil Price Fluctuations and Changing Comparative Advantage. Sosyoekonomi Journal, 2, 108-130.

Balassa, B. (1965). Trade Liberalization and Revealed Comparative Advantage. Manchester School of Economics and Social Studies, 33, 99-123.

Balassa, B. (1989). Comparative Advantage, Trade Policy and Economic Development. New York: Harvester Wheatsheaf.

Bank Negara Malaysia. (BNM) (2015). Economic and Financial Developments in the Malaysian Economy in the First Quarter of 2015. Developments in the Malaysian Economy. Quarterly Bulletin. Kuala Lumpur.

Bank Negara Malaysia. (BNM) (2016). Economic and Financial Developments in the Malaysian Economy in the First Quarter of 2016. Developments in the Malaysian Economy. Quarterly Bulletin. Kuala Lumpur.

Bender, S., \& Li, K. W. (2002). The Changing Trade and Revealed Comparative Advantages of Asian and Latin American Manufacture Exports. Yale University, Economic Growth Center. Discussion Paper Series, No.843.

Bhattacharya, R. (2011). Revealed Comparative Advantage and Competitiveness: A Case Study for India in Horticultural Products. International Conference on Applied Economics.

Choong, C. K., Yusop, Z., Law, S. H., \& Liew, V. K. S. (2003). Financial Development and Economic Growth in Malaysia: A Re-assessment from Bound Test Approach. Labuan Bulletin of International Business and Finance, Inaugural issues, 53-63. 
Choong, C. K., Yusop, Z., Law, S. H., \& Liew, V. K. S. (2005). Financial Development and Economic Growth in Malaysia: The Stock Market Persprective. Investment Management and Financial Innovations, 2(4), 105-115.

Cvetković, M., \& Petrović-Ranđelović, M. (2017). The Analysis of Agricultural Products Export Competitiveness of the Republic of Serbia based on the RCA Index. Economic Themes, 55(3), 399-420.

Department of Statistics Malaysia. (DOSM) (2016). Gross Fixed Capital Formation 2010-2015. https://www.statistics.gov.my/index.php?r=column/pdfPrev\&id=cDVaZFp0elRCTVFiU GNIVmovU3pTQT09

Diao, X., Hazell, P., Resnick, D., \& Thurlow, J. (2007). The Role of Agriculture in Development. Implications for Sub-Saharan Africa. International Food Policy Research Institute: Washington, D.C., USA.

Economic Planning Unit. (EPU) (2015). Eleventh Malaysia Plan 2016-2020. Chapter 1: Anchoring Growth on People. Kuala Lumpur: Malaysia. Government Printing Office.

Edeme, R. K., Ifelunini, I. A., \& Nkalu, N. C. (2016). A Comparative Analysis of the Impact of Agricultural Exports on Economic Growth of ECOWAS Countries. Acta Oeconomica Pragensia, 24(5), 31-46.

European Commission. (2007). EU Industrial Structure 2007. http://ec.europa.eu/enterprise/policies/industrialcompetitiveness/competitivenessanalysis/eu-industrial-structure/index en.htm

Food and Agriculture Organization of the United Nations. (FAO) (2012). World Food and Agriculture. Rome: Economic and Social Development Department.

Ismail, R., \& Yuliyusman, F. (2014). Foreign Labour on Malaysian Growth. Journal of Economic Integration 29(4), 657-675.

Joshi, P. K., Gulati, A., Birthal, P. S., \& Tewari, L. (2004). Agriculture Diversification in South Asia: Patterns, Determinants and Policy Implications. Economic and Political Weekly, 39(24), 2457-2467.

Le, Q. P. (2010). Evaluating Vietnam's Changing Comparative Advantage Patterns. ASEAN Economic Bulletin, 27(2), 221-230.

Lembaga Getah Malaysia. (2011). The Malaysian Natural Rubber Industry. http://www.lgm.gov.my/GreenMaterial/TheMalaysianNRIndustry.pdf

Madsen, J. B., \& Ang, J. B. (2013). The Asian Growth Miracle: Factor Accumulation, the Demographic Transition, and $R$ and D Driven Growth. (Monash Economics Working Papers No 23-13). Department of Economics, Monash University.

Malaysia Palm Oil Council. (2013). Malaysia Palm Oil Industry. http://www.mpoc.org.my/Malaysian_Palm_Oil_Industry.aspx

Malaysia Productivity Corporation. (MPC) (2015). Productivity Report 2014/2015. Selangor, Malaysia.

Malaysia Productivity Corporation. (MPC) (2016). Productivity Report 2015/2016. Selangor, Malaysia.

Malaysian Investment Development Authority. (MIDA) (2016). Services Sector. Retrieved January 30, 2017, from http://www.mida.gov.my/home/services-sector/posts/

Malik, S. K. (2012). Capital Goods Sector in India, 1990-91 to 2009-10. Paper presented at the $8^{\text {th }}$ International PhD school on Innovation and Development, GLOBELICS Aademy, Rio de Janeiro, Brazil. 
Mehrara, M., \& Baghbanpour, J. (2016). The Contribution of Industry and Agriculture Exports to Economic Growth: The Case of Developing Countries. World Scientific News, 46, 100111.

Ministry of Plantation Industries and Commodities. (MPIC) (2016). PEPPER: MPB to Create More Downstream Products. https://www.mpic.gov.my/mpic/index.php/en/rss-contentenglish/1583-

Moreno, R. M. (2016). Immigrant Labor: Can it Help Malaysia's Economic Development? The World Bank. http://blogs.worldbank.org/eastasiapacific/immigrant-labor-can-it-helpmalaysia-s-economic-development

Mucavele, F. G. (2010). True Contribution of Agriculture to Economic Growth and Poverty Reduction: Malawi, Mozambique and Zambia Synthesis Report. Food Agriculture and Natural Resources Policy Analysis Network.

Narayan, P. K. (2005). The Saving and Investment Nexus for China: Evidence from Cointegration Tests. Journal of Applied Economics, 19(2), 245-261.

Nilsson, F. O. L., Lindberg, E., \& Surry, Y. (2007). Are the Mediterranean Countries Competitive in Fresh Fruit and Vegetable Exports? (SLU Working Paper Series No. 1) Swedish University of Agricultural Sciences (SLU).

Othman, P., Sungkar, I., \& Wan Hussin, W. S. (2009). Malaysia as an International Halal Food Hub: Competitiveness and Potential of Meat-based Industries. ASEAN Economics Bulletin, 26(3), 306-320.

Pesaran, M., Shin, Y., \& Smith, R. J. (2001). Bound Testing Approaches to the Analysis of Level Relationships. Journal of Applied Econometrics, 16(3), 289-326.

Pham, T. T. T., \& Riedel, J. (2013). An Empirical Analysis of Comparative Advantage Dynamics. FREIT Working Paper No 633.

Ruban, A. (2016 May, 25). Why Malaysia Imports Vegetables. Malay Mail Online. http://www.themalaymailonline.com/malaysia/article/why-malaysia-importsvegetables\#guZqMYI6FjhlLa9i.97

Schwab, K., \& Sala-i-Martin, X. (2014). The Global Competitiveness Report 2014-2015. World Economic Forum, Geneva. http://www3.weforum.org/docs/WEF_GlobalCompetitivenessReport_2014-15.pdf

Tengku Ahmad, T. M. A., \& Suntharalingam, C. (2009). Transformation and Economic Growth of the Malaysian Agricultural Sector. Economic and Technology Management Review, 4, $1-10$.

Tuah, Y. (2013 August, 25). Commodities: Malaysia's Natural Treasures. The Borneo Post. http://www.theborneopost.com/2013/08/25/commodities-malaysias-natural-treasures/

Verick, S. (2014). Female Labor Force Participation in Developing Countries. IZA World of Labor, 87, 1-10. https://doi.org/10.15185/izawol.87

Welfen, P. J. J., Ryan, C., Chirathivat, S., \& Knipping, F. (2009). EU-ASEAN: Facing Economic Globalisation. In P. J. J. Welfen, \& D. Borbély (Eds.). Structural Change, Growth and Bazaar Effects in the Single EU Market (pp.7-35). Berlin, Heidelberg: Springer-Verlag.

Wik, M., Pingali, P., \& Broca, S. (2008). Global Agricultural Performance: Past Trends and Future Prospects. Background Paper for the World Development Report 2008. Washington, D.C.: The World Bank.

World Economic Forum. (2015). Country Highlights. Retrieved on May 20, 2016, from http://reports.weforum.org/global-competitiveness-report-2015-2016/country-highlights

Zhu, X. (2012). Understanding China's Growth: Past, Present and Future. Journal of Economic Perspectives, 26(4), 103-124. 
Appendix A: Results of Agricultural Products with Revealed Comparative Advantage

S\#-016 Meat and edible meat offal, salted, in brine, dried or smoked; edible flours and meals of meat or meat offal

S3-01689

S\#-034 Fish, fresh (live or dead), chilled or frozen S3-03414

S\#-036 Crustaceans, molluscs and aquatic invertebrates, whether in shell or not, fresh (live or dead), chilled, frozen, dried, salted or in brine; crustaceans, in shell, cooked by steaming or boiling in water, whether or not chilled, frozen, dried, salted or in brine; flours, meals and pellets of crustaceans or of aquatic invertebrates, fit for human consumption

S3-03611

S3-03633

S3-03637

S\#-037 Fish, crustaceans, molluscs and other aquatic invertebrates, prepared or preserved, n.e.s.

S3-03713

S3-03715

S3-03721

S\#-047 Other cereal meals and flours

S3-04719

S\#-048 Cereal preparations and preparations of flour or starch of fruits or vegetables

S3-04812

S3-04813

S\#-054 Vegetables, fresh, chilled, frozen or simply preserved (including dried leguminous vegetables); roots, tubers and other edible vegetable products, n.e.s., fresh or dried

S3-05452

S3-05483

S\#-056 Vegetables, roots and tubers, prepared or preserved, n.e.s.

S3-05645

S3-05647

S3-05648

S\#-057 Fruit and nuts (not including oil nuts), fresh or dried

S3-05729

S3-05779

S3-05791

S3-05795

S3-05798

S\#-058 Fruit, preserved, and fruit preparations (excluding fruit juices)

S3-05893

S\#-061 Sugars, molasses and honey

S3-06194

S\#-071 Coffee and coffee substitutes

S3-07131

S3-07132

S\#-072 Cocoa

S3-07231

S3-07232

S\#-075 Spices

S3-07511

S3-07512

S3-07523

S3-07524

S3-07527

S\#-081 Feeding stuff for animals (not including unmilled cereals) S3-08138

S\#-098 Edible products and preparations, n.e.s. 


\begin{tabular}{|l|l|}
\hline & S3-09811 \\
\hline & S3-09894 \\
\hline S3-09891 \\
\hline S\#-122 & Tobacco, manufactured (whether or not containing tobacco substitutes) \\
\hline & S3-12232 \\
\hline & S3-12239 \\
\hline S3-29299 \\
\hline S\#-421 & Fixed vegetable fats and oils, "soft", crude, refined or fractionated \\
\hline & S3-42119 \\
\hline S3-42179 \\
\hline & Fixed vegetable fats and oils, crude, refined or fractionated, other than "soft" \\
\hline & S3-42229 \\
\hline & S3-42231 \\
\hline & S3-42239 \\
\hline & S3-42241 \\
\hline S3-42249 \\
\hline & $\begin{array}{l}\text { Animal or vegetable fats and oils, processed; waxes; inedible mixtures or preparations of animal } \\
\text { or vegetable fats or oils, n.e.s. }\end{array}$ \\
\hline & S3-43131 \\
\hline S3-431 & \\
\hline &
\end{tabular}

